\title{
Blended Learning Station-Rotation Model: Does it Impact on Preservice Teachers' Scientific Literacy?
}

\author{
Gito Hadiprayitno ${ }^{1 *}$, Kusmiyati ${ }^{1}$, Ayudya Lestari ${ }^{1}$, Marheny Lukitasari², Akhmad Sukri ${ }^{3}$ \\ ${ }^{1}$ Biology Education, Faculty of Teacher Training and Education, University of Mataram, Indonesia \\ ${ }^{2}$ Biology Education of University of PGRI Madiun, Indonesia \\ ${ }^{3}$ Biology Education of University of Pendidikan Mandalika, Indonesia
}

DOI: $10.29303 /$ jppipa.v7i3.676

\section{Article Info}

Received : March 10th 2021

Revised : May 20th 2021

Accepted: May 25th, 2021

\begin{abstract}
This study aims to test the effectiveness of the blended learning rotation model to improve the scientific literacy skill of prospective teacher students. The design of this study used the Posttest-only design with nonequivalent groups. The research subjects were 76 students majoring in biology education at Universitas Mataram. The research was done to two experimental groups, namely the blended learning station rotation model (BLSRM) and regular learning (RL). The research instrument used a multiple-choice test which refers to the aspects of scientific literacy competence according to PISA. The data analysis technique was carried out descriptively, complete with the Hotelling's T2 test to test the effect of BLSRM on students' scientific literacy skills. The results showed that students' scientific literacy skills were in the very low category (mean BLSRM $=38.50, \mathrm{RL}=34.22$ ) and there was no effect of BLSRM on students' scientific literacy skills (Hotteling Trace = .098 and Sig. $=.080)$. To improve students' scientific literacy skills, BLSRM needs to be combined with other models such as problem-solving model, so it can be an effective strategy in science learning.
\end{abstract}

Keywords: blended learning; station rotation model; science literacy

Citation: Hadiprayitno, G., Kusmiyati, K., Lestari, A., Lukitasari, M., \& Sukri, A. (2021). Blended Learning Station-Rotation Model: Does it Impact on Preservice Teachers' Scientific Literacy?. Jurnal Penelitian Pendidikan IPA, 7(3), 317-324. doi:https:// doi.org/10.29303/ippipa.v7i3.676

\section{Introduction}

The industrial world has now entered the era of Industrial Revolution 4.0. The Industrial Revolution 4.0 is a strategic initiative introduced by the German government with the aim of transforming the manufacturing industry through digitalization and exploitation of the new technology's potential (Rojko, 2017). In general, the Industrial Revolution 4.0 refers to the means of automation and data exchange in manufacturing technologies including Physical-Cyber Systems, Internet of Things, big data and analytics, additive manufacturing, simulation, horizontal and vertical system integration, autonomous robots, and cloud computing (Tay et al. al, 2018). The Industrial Revolution 4.0 is a digital era and all activities related to industry are mostly connected through the internet or cyber system (Syamsuar \& Reflianto, 2018). This industry is characterized by flexibility, efficient use of resources, integration of customers and business partners in business processes, artificial intelligence, three-dimensional printing, and nanotechnology (Vuksanovic et al, 2016; Ghufron, 2018).

The Industrial Revolution 4.0 has an impact on education in Indonesia. The education system in Indonesia needs to adapt to the needs of the Industrial Revolution 4.0 era. Therefore, learning innovations and learning curricula need to be designed to improve student understanding in Information Technology (IT), Operational Technology (OT), Internet of Things (IoT), and Big Data Analytics (Iswan and Bahar, 2018). In this regard, industrial development in the Industrial 
Revolution 4.0 era will have an impact on the learning process carried out in higher education. Therefore, in terms of learning, educators need to understand the technological developments and changes in learning methods along with technological advances that are currently developing (Sukartono 2018). One of the ways that needs to be prepared in the face of the industrial revolution era is to design and implement more innovative learning models (Syamsuar \& Reflianto, 2018). One of the innovative learning models that can be implemented in the era of Industrial Revolution 4.0 is blended learning.

Blended learning is a learning model that combines online and offline learning (Bender \& Vredevoogd, 2006). Blended learning is an innovative concept that corporates the advantages of traditional classroom teaching along with ICT-supported learning including offline learning and online learning (Lalima \& Dangwal, 2017). Blended learning combines traditional (face-to-face) aspects and the use of technology for distant learning in the learning process (Cianda et al, 2019). Blended learning is a balance between face-to-face and online learning (Morton et al, 2016). With blended learning, students can construct their own knowledge and change their passive behavior that only receives knowledge from their teacher into an active behavior (Maza et al, 2016; Wichadee, 2017). Blended learning has been shown to improve student learning's outcomes (Saritepeci \& Cakir, 2015; Rafiola et al, 2020; Ridwan et al, 2020), can improve critical and creative thinking (Nurkhin et al, 2020), can increase student's motivation in learning (Schober \& Keller, 2012; Islam et al, 2018), are used as important guidelines in learning (Cao \& Liu, 2019), and as an alternative learning method in higher education (Ibrahim \& Nat, 2019).

According to Horn \& Staker (2011), blended learning is divided into four, namely the rotation model, flex model, self-blended model and enrichedvirtual model. Furthermore, the rotation model is divided into 4, namely the station-rotation model, labrotation model, flipped-classroom model and individual-rotation model (Ayob et al, 2020). The use of the rotation model has been widely used and has been proven to be effective in learning (Govindaraj \& Silverajah, 2017); Ayob et al, 2020). In Indonesia, the rotation model of blended learning has been implemented often to improve the learning process (Ridwan et al, 2020), to improve student learning's outcomes (Rafiola et al, 2020), to improve students' intrapersonal intelligence (Ambarli et al, 2020), and to improve students' high level thinking skills (Christina et al, 2019). However, not many literatures examine the effect of the rotation model of blended learning on improving students' scientific literacy skills. On the other hand, the results of the scientific literacy skills measurement of students in Indonesia by PISA in 2018 revealed that the scientific literacy skills of Indonesian students were at a very low level (OECD, 2019). This is a serious matter for Indonesian government, education practitioners, and researchers in Indonesia to find the suitable concepts and the appropriate learning models to improve students' scientific literacy skills. This study wants to answer the research question, namely whether the rotation model of blended learning is suitable to be used to improve students' literacy skills. Meanwhile, the purpose of this study is to test the effectiveness of the rotation model of blended learning to improve students' scientific literacy skills. State the objectives of the work and provide an adequate background, avoiding a detailed literature survey or a summary of the results.

\section{Method}

This research is an experimental study using a posttest-only research design with nonequivalent groups (Shadish et al, 2002; Hastjarjo, 2019). In the experimental class, the treatment used is the blended learning station rotation model (BLSRM), while in the control class the treatment used is regular learning (RL). In BLSRM learning, a series of learning activities are arranged alternately from one activity to another through online learning scheme - face to face learning online learning (Ayob et al, 2020), while for the control class the learning activities are using RL through face to face. Learning activities are carried out for one semester, which lasts for 10 meetings. After completion of the treatment, the scientific literacy posttest was given to each experimental class. The research subjects consisted of 76 prospective biology teacher students from the Teacher Training and Education Faculty of Universitas Mataram, including men and women, aged 19 to 20 years, with different ethnicities.

The research instrument used was a multiplechoice test which refers to the aspects of scientific literacy competence according to PISA (OECD, 2016) which has been modified and adapted to the Indonesian context covering 3 aspects and 15 indicators (Table 1). Before the instrument was used, first the validity and reliability tests were carried out using the Pearson correlation and Cronbach'salpha tests (reliability $=0.8)$. The raw score of scientific literacy is converted into a nominal scale (Purwanto, 2010) which is further categorized into 5 categories, namely a score of $86-100=$ very good, a score of $76-85=$ good, a score of $60-75=$ sufficient, a score of 55-59 = less, and a score $\leq 54=$ very poor. The analysis of research data is by descriptive and inferential statistical analysis using Hotelling's T2 (Srivastava, \& Mudholkar, 2001; Willems 
et al, 2002). Descriptive statistical analysis was used to describe the independent variable being tested, while Hotelling's T2 was used to test the effect of BLSRM on students' scientific literacy skills. Research design and method should be clearly defined.

Table 1: Characteristics of the research instrument

\begin{tabular}{|c|c|c|}
\hline $\begin{array}{l}\text { Scientific Literacy } \\
\text { Aspect }\end{array}$ & Indicator & $\begin{array}{l}\text { Question } \\
\text { number }\end{array}$ \\
\hline Explaining a & Recalling and applying scientific knowledge appropriately (A1) & 1,2 \\
\hline phenomenon & Identifying, using, and producing an explanation of a model or representation (A2) & $3,4,5,6$ \\
\hline \multirow[t]{3}{*}{ scientifically (A) } & Creating and offering a reason for a prediction appropriately (A3) & $7,8,9,10$ \\
\hline & Offering an explanation of a hypothesis (A4) & 11,12 \\
\hline & Explaining the potency of scientific knowledge implication to the society (A5) & 13,14 \\
\hline \multirow{5}{*}{$\begin{array}{l}\text { Evaluating and } \\
\text { designing scientific } \\
\text { research (B) }\end{array}$} & Identifying the questions that is being explored in a given scientific research (B1) & 15,16 \\
\hline & Distinguishing the questions that can be investigated scientifically (B2) & 17 \\
\hline & Proposing a way to explore questions scientifically (B3) & 18 \\
\hline & Evaluating how to explore questions scientifically (B4) & 19 \\
\hline & $\begin{array}{l}\text { Describing and evaluating how researchers prove the reliability of the data and } \\
\text { generalizing an explanation (B5) }\end{array}$ & 20 \\
\hline \multirow{5}{*}{$\begin{array}{l}\text { Intrepreting the data } \\
\text { and proving the data } \\
\text { scientifically }(\mathrm{C})\end{array}$} & Transforming the data from a representation to another $(\mathrm{C} 1)$ & 21 \\
\hline & Analyzing and interpreting data and making conclusions appropriately (C2) & 22 \\
\hline & Identifying an assumption, proof, and reasoning in a text related to science (C3) & 23 \\
\hline & $\begin{array}{l}\text { Distinguishing arguments based on evidence and scientific theory and those based } \\
\text { on other considerations (C4) }\end{array}$ & 24 \\
\hline & $\begin{array}{l}\text { Evaluating an argument and proof from different sources (newspaper, internet, } \\
\text { journal, etc.) (C5) }\end{array}$ & 25 \\
\hline
\end{tabular}

\section{Result and Discussion}

This study reveals students' scientific literacy skills in 3 aspects and 15 indicators as shown in Table 1. The assessment of students' scientific literacy skills was carried out after the learning using BLSRM and RL was given. The results of students' scientific literacy skills in each aspect and indicators of literacy competence are shown in Table 2. Based on Table 2, the lowest result of students' scientific literacy skills is found in the A1 indicator (recalling and applying scientific knowledge appropriately) with a value of 18.10 in the RL group. Remembering is a part of Bloom's taxonomy which is included in the C1/knowledge level (Dinni, 2018). However, the skill to remember alone is not enough because one's knowledge will only be meaningful if it can be applied in solving problems (Suryapuspitarini et al, 2018). The low skill of students' scientific literacy on the A1 indicator is thought to be caused by the low skill of students to apply their scientific knowledge. This is supported by Nofiana (2017) who states that active experimentation (doing) in learning needs to be developed to foster one's scientific literacy skills.

In addition, another low result is also found in the A2 indicator (identifying, using, producing an explanation of a model or representation) in the BLSRM and RL groups with scores of 27.50 and 31.90, respectively. Models or representations can be in the form of diagrams, graphs, verbal, or mathematical which are used to simplify a real object. According to
Sujarwanto et al (2014), the skill to use models or representations is strongly influenced by problem solving skills. This low problem-solving skill is thought to be the cause of why students are facing difficulty in presenting an explanation of a model or representation. Meanwhile, the students' highest result was on the A4 indicator (offering an explanation of a hypothesis), both the BLSRM and RL groups with scores of 72.50 and 73.60 , respectively. These results indicate that there is no difference in between the two experimental groups. According to Asyhari \& Clara (2017), the skill to offer an explanation of a hypothesis is an activity to formulate alternative solutions in problem-solving in order to prove a hypothesis. This skill is influenced by internal factors including self-confidence (Aisyah, 2016).

In the aspect of evaluating and designing scientific investigations, the lowest result of students' scientific literacy skills is on the B4 indicator (evaluating how to explore questions scientifically). The value of the B4 indicator in the BLSRM and RL groups is 7.50 and 8.30 , respectively. Meanwhile, the highest score of scientific literacy competence in this aspect is in the B3 indicator (proposing a way to explore questions scientifically) with the score of 47.50 and 44.40 for the BLSRM and RL groups respectively. Indicators B3 and B4 are related to one another. Supposedly, when students can propose ways to explore questions scientifically, students can also linearly evaluate how to explore questions scientifically. This is also confirmed 
by Arina (2016). However, the result of this study indicates the opposite. The low evaluation skill of the students is influenced by their reasoning skill (Arina, 2016). This is what is thought to be the cause of the low evaluation skill of students.

Based on Table 2, in the aspect of interpreting data and proving data scientifically, students' scientific literacy skill is the lowest in indicator C2 (analyzing and interpreting data and making conclusions appropriately). In the RL group, the literacy competency score was 22.20. Based on the SOLO taxonomy theory (Ekawati et al, 2013), a low skill to create conclusions is categorized at the unistructural level. At this level, a person is able to use the selected data to solve the problem but the conclusions do not match the data. On the other hand, the highest scientific literacy competency score in this aspect is on the C4 indicator (distinguishing arguments based on evidence and scientific theory and those based on other considerations) with a score in the BLSRM group of 72.50. If an argument is based on evidence, then the position of the evidence can be considered as a form of logical argument in explaining the truth of a statement (Nurrahman \& Karim, 2018; Soekisno, 2015; Ramdani, 2012). In addition to being based on evidence, according to Budiyono et al, (2015) arguments can also be based on the presence of data to present a claim that proves the argument is accurate and its true value is indisputable. Based on the results of this study, the fairly high result of students on the $\mathrm{C} 4$ indicator in the BLSRM group shows that students have been able to distinguish arguments originating from evidence and data compared to sources based on other considerations that have not been proven true.

Table 2: The result of students' scientific literacy skills from every aspect and competence indicator

\begin{tabular}{llllll}
\hline $\begin{array}{l}\text { Literacy } \begin{array}{c}\text { aspect } \\
\text { A }\end{array} \\
\text { Andicator }\end{array}$ & $\begin{array}{l}\text { Score per } \\
\text { indicator }\end{array}$ & $\begin{array}{l}\text { Scor per literacy } \\
\text { aspect }\end{array}$ \\
\cline { 3 - 6 } & ALSRM & RL & BLSRM & RL \\
\hline & A2 & 38.75 & 18.10 & 43.75 & 38.30 \\
& A3 & 32.50 & 31.90 & & \\
& A4 & 72.50 & 73.60 & & \\
B & A5 & 47.50 & 36.10 & & \\
& B1 & 35.00 & 29.20 & 26.00 & 27.50 \\
& B2 & 27.50 & 25.00 & & \\
& B3 & 47.50 & 44.40 & & \\
C & B4 & 7.50 & 8.30 & & \\
& B5 & 12.50 & 30.60 & & \\
& C1 & 25.00 & 25.00 & 48.00 & \\
& C2 & 32.50 & 22.20 & & \\
& C3 & 65.00 & 52.80 & & \\
& C4 & 72.50 & 47.20 & & \\
& C5 & 45.00 & 30.60 & & \\
\hline
\end{tabular}

After describing the student' scientific literacy skills for each aspect and competency indicators in each experimental group, a descriptive analysis was carried out to determine the statistical parameters of students' scientific literacy skill (Table 3). Based on Table 3, it is known that the average scientific literacy skills of students in the BLSRM group was 38.50, which is slightly higher than the RL group which was 34.22. These results indicate that the scientific literacy skills of students in the two experimental groups are not much different and in the same category, namely the very low category. The results obtained reinforce the results of the 2018 PISA measurements which found that the level of scientific literacy of students in Indonesia is very low (OECD, 2019). This result is reinforced by various other researches conducted in several other regions in Indonesia which found the same trend as the results (Fakhriyah et al, 2017; Fitriani et al, 2018; and Sinaga et al, 2019). The low skill of students' scientific literacy is likely due to several factors such as family background, individual knowledge, speaking skills (Heath et al., 2014), student reasoning levels, and the skill to connect many disciplines (Holbrook \& Rannikmae, 2009). Another thing that is thought to be the cause of the low skill of students' scientific literacy in the two experimental groups is that students are not used to and less trained in working on problems with highlevel thinking characteristics such as scientific literacy questions adopted from PISA. This is in accordance with the research of Fatmawati \& Utari (2015) that found the same thing causing the low literacy skills of students. The results that have been obtained need to be strengthened by using statistical tests to determine the effect of BLSRM model learning on students' scientific literacy skills. The results of the T2 Hotteling Test analysis to determine the effect of BLSRM on scientific literacy skills in each aspect of literacy competence are shown in Tables 4 and 5.

Table 3: Scientific literacy skills of students from both experimental groups

\begin{tabular}{lll}
\hline \multirow{2}{*}{ Descriptor } & \multicolumn{2}{l}{ Experimental group } \\
\cline { 2 - 3 } & BLSRM & RL \\
\hline $\mathrm{N}$ & 40 & 36 \\
Ideal maximum score & 100 & 100 \\
Higest score & 56 & 60 \\
Lowest score & 16 & 24 \\
\hline Mode & 44 & 28 \\
Median & 40 & 32 \\
Average & 38.50 & 34.22 \\
Standart deviation & 10.63 & 7.73 \\
Category & Very low & Very low \\
\hline
\end{tabular}

Based on Table 4, Box's Test of Equality of Covariance Matrics shows that the variance-covariance 
matrix between BLSRM and RL is homogeneous (Sig. = $.106>$.05), while the result of the analysis of homogenity variance for each aspect of scientific literacy competence shows homogeneous data. (Sig. = $.076 ; .990$ and .981> .05). Based on these results, further analysis using T2 Hotteling Test can be performed (Table 5). The result of the analysis in Table 5 shows that the Hotteling Trace value is .098 with the Sig. amounting to .080 (Sig.> .05). This indicates that there is no effect of the BLSRM treatment group on students' scientific literacy skills in each competency aspect.

Blended learning has been shown to give an effect on student's learning outcomes (Banyen et al, 2016; Obiedat et al, 2014; Bi \& Shi, 2019) and helps the learning process in the classroom because it is easy, accessible, flexible and independent (Divayana, 2019; Rasmitadila et al, 2020). In particular, the rotation model of blended learning can support learning (Govindaraj \& Silverajah, 2017), improve learning outcomes (Ayob et al, 2020), and improve students' intrapersonal intelligence (Ambarli et al, 2020). In addition, this rotation blended learning model is very suitable to be implemented on campuses, especially Polytechnics in Indonesia (Dewi et al, 2018). Previous research results also revealed that BLSRM can improve students 'high-level thinking skills (Christina et al, 2019), but it is very difficult to find research results that reveal the effect of BLSRM on students' scientific literacy skills. Table 5 reveals that there is no effect of BLSRM on students' scientific literacy skills.

The results of this study reinforce the previous hypothesis which states that to improve scientific literacy skills, a learning model that can facilitate scientific literacy such as scientific investigations is needed so that students can actively construct their knowledge (Fatmawati \& Utari, 2015). In this study, BLSRM learning was not combined with other methods that could improve students' literacy skills. This is supposedly the cause of why BLSRM learning has no effect on students' scientific literacy skills. BLSRM learning has been proven to improve learning outcomes, interpersonal intelligence and high-level thinking skills of students, but to improve scientific literacy skills, BLSRM learning needs to be combined with other methods such as problem solving so students can develop literacy skills such as explaining scientific phenomena, designing investigations, and interpreting and prove the data scientifically. This is reinforced by the opinion of Stockwell et al (2015) which states that the blended learning model combined with problem solving is an effective strategy in science learning.
Table 4: Result of BLSRM-RL covariance-variance matrix homogeneity and students' literacy skills on every competence aspect.

\begin{tabular}{|c|c|c|c|c|c|}
\hline Dependent & Indepen & t Varia & & & \\
\hline Box's M = & Literacy & $\mathrm{F}$ & df1 & df2 & Sig. \\
\hline $\begin{array}{l}10.958 \\
d f 1\end{array}$ & Aspect & 3235 & 1 & 74 & 076 \\
\hline $\begin{array}{l}d f 1 \\
d f 2\end{array}$ & B & .000 & 1 & 74 & 990 \\
\hline 38464.819 & & & & & \\
\hline$=.106$ & C & .001 & 1 & 74 & .981 \\
\hline
\end{tabular}

Tabel 5: Hotteling Test T2 analysis result

\begin{tabular}{|c|c|c|c|c|c|c|c|}
\hline Effect & & Value & F & $\begin{array}{l}\text { Hypo } \\
\text { thesis } \\
\text { df }\end{array}$ & $\begin{array}{l}\text { Error } \\
\text { df }\end{array}$ & Sig. & $\begin{array}{l}\text { Partial } \\
\text { Eta } \\
\text { Squared }\end{array}$ \\
\hline \multirow{9}{*}{$\begin{array}{l}\text { Inter } \\
\text { cept }\end{array}$} & Pillai's & .940 & 376.402 & 3.000 & 72.000 & .000 & .940 \\
\hline & Trace & & a & & & & \\
\hline & Wilks' & .060 & 376.402 & 3.000 & 72.000 & .000 & .940 \\
\hline & Lambda & & a & & & & \\
\hline & Hotelling' & ' 15.683 & 376.402 & 3.000 & 72.000 & .000 & .940 \\
\hline & s Trace & & a & & & & \\
\hline & Roy's & 15.683 & 376.402 & 3.000 & 72.000 & .000 & .940 \\
\hline & Largest & & a & & & & \\
\hline & Root & & & & & & \\
\hline \multirow[t]{5}{*}{ Group } & Pillai's & .089 & $2.348 \mathrm{a}$ & 3.000 & 72.000 & .080 & .089 \\
\hline & Trace & & & & & & \\
\hline & $\begin{array}{l}\text { Wilks' } \\
\text { Lambda }\end{array}$ & .911 & $2.348 \mathrm{a}$ & 3.000 & 72.000 & .080 & .089 \\
\hline & $\begin{array}{l}\text { Hotelling' } \\
\text { s Trace }\end{array}$ & '.098 & $2.348 \mathrm{a}$ & 3.000 & 72.000 & .080 & .089 \\
\hline & $\begin{array}{l}\text { Roy's } \\
\text { Largest } \\
\text { Root }\end{array}$ & .098 & $2.348 \mathrm{a}$ & 3.000 & 72.000 & .080 & .089 \\
\hline
\end{tabular}

\section{Conclusion}

The rotation model of blended learning is widely used because it supports classroom learning which has the characteristics of being accessible, easy, flexible, and independent. In addition, this learning is also proven to improve learning outcomes, intrapersonal intelligence, and students' higher order thinking skills. The result of this study reveals that there is no effect of the rotation model of blended learning on students' scientific literacy skills. Based on these findings, to improve students' scientific literacy skills then BLSRM learning needs to be combined with other models such as problem solving, so that it can be an effective strategy in science learning. BLSRM combined with problem solving is expected to develop students' literacy skills such as explaining scientific phenomena, designing investigations and interpreting and proving data scientifically. 


\section{References}

Aisyah, A. (2016). Studi literatur: Pendekatan induktif untuk meningkatkan kemampuan generalisasi dan self confident siswa SMK. JP3M (Jurnal Penelitian Pendidikan dan Pengajaran Matematika), 2(1), 1-12. doi: http://dx.doi.org/10.37058/jp3m.v2i1.148 [Indonesian]

Ambarli, S., Syahrial, Z., \& Sukardjo, M. (2020). Pengaruh Model Blended Learning Rotasi dan Kecerdasan Intrapersonal Terhadap Hasil Belajar IPA di SMP. Visipena, 11(1), 16-32. doi: https://doi.org/10.46244/visipena.v11i1.1089 [Indonesian]

Arini, Z. (2016). Profil Kemampuan Penalaran Siswa SMP dalam Menyelesaikan Masalah Matematika Ditinjau dari Tipe Kepribadian Extrovert dan Introvert. MATHEdunesa, 5(2). [Indonesian]

Asyhari, A., \& Clara, G. P. (2017). Pengaruh Pembelajaran Levels of Inquiry Terhadap Kemampuan Literasi Sains Siswa. Scientiae Educatia: Jurnal Pendidikan Sains, 6(2), 87-101. doi: https://doi.org/10.24235/sc.educatia.v6i2.2000 [Indonesian]

Ayob, N. F. S., Abd Halim, N. D., Zulkifli, N. N., Zaid, N. M., \& Mokhtar, M. (2020). Overview of Blended Learning: The Effect of Station Rotation Model on Students'achievement. Journal of Critical Reviews, 7(6), 320-326. doi: https://doi.org/10.31838/jcr.07.06.56

Banyen, W., Viriyavejakul, C., \& Ratanaolarn, T. (2016). A Blended Learning Model for Learning Achievement Enhancement of Thai Undergraduate Students. International Journal of Emerging Technologies in Learning, 11(4), 48-55. doi: https://doi.org/10.3991/ijet.v11i04.5325

Bender, D. M., \& Vredevoogd, J. D. (2006). Using online education technologies to support studio instruction. Journal of Educational Technology $\mathcal{E}$ Society, 9(4), 114-122.

Bi, X., \& Shi, X. (2019). On the Effects of ComputerAssisted Teaching on Learning Results Based on Blended Learning Method. International Journal of Emerging Technologies in Learning (iJET), 14(01), 58-70.

doi: https://doi.org/10.3991/ijet.v14i01.9458

Budiyono, A., Rusdiana, D., \& Kholida, S. I. (2015). Pembelajaran Argument Based Science Inquiry (ABSI) Pada Fisika. Prosiding Simposium Nasional Inovasi dan Pembelajaran Sains 2015 (SNIPS 2015), 8, 205-208. [Indonesian]

Cao, S., \& Liu, H. (2019). Effectiveness Analysis of Edmodo-Based Blended English Learning Mode. International Journal of Emerging
Technologies in Learning (iJET), 14(18), 64-75. doi: https://doi.org/10.3991/ijet.v14i18.11184

Christina, S., Rusijono, R., \& Bachtiar, B. (2019). The Application of Blended Learning's Station Rotation Method in Elementary School's Science Education to Improve Higher Order Thinking Skills. Dinamika Jurnal Ilmiah Pendidikan Dasar, 11(2), 79-85. doi: https://doi.org/10.30595/dinamika.v11i2.5048

Cianda, F., Burhendi, A., WD, L., \& Kusdiwelirawan, A. (2019). Implementation of Blended Learning to Use Discovery Learning Method. Int. J. Innov. Creat. Chang, 5(6), 153-163.

Dewi, K. C., Ciptayani, P. I., Surjono, H. D., \& Priyanto, P. (2018). Study of Instructional Model on Blended Learning in Polytechnic. Cakrawala Pendidikan, XXXVII(2), 270-281. doi: https://doi.org/10.21831/cp.v37i2.18267

Dinni, H. N. (2018, February). HOTS (High Order Thinking Skills) dan kaitannya dengan kemampuan literasi matematika. In PRISMA, Prosiding Seminar Nasional Matematika (Vol. 1, pp. 170-176).

Divayana, D. (2019). The implementation of blended learning with Kelase platform in the learning of assessment and evaluation course. International Journal of Emerging Technologies in Learning (iJET), 14(17), 114-132. doi: https://doi.org/10.3991/ijet.v14i17.8308

Ekawati, R., Junaedi, I., \& Nugroho, S. E. (2013). Studi respon siswa dalam menyelesaikan soal pemecahan masalah matematika berdasarkan taksonomi SOLO. Unnes Journal of Mathematics Education Research, 2(2), 101-107. [Indonesian]

Fakhriyah, F., Masfuah, S., Roysa, M., Rusilowati, A., \& Rahayu, E. S. (2017). Student's Science Literacy in the Aspect of Content Science?. Jurnal Pendidikan IPA Indonesia, 6(1), 81-87. doi: https://doi.org/10.15294/jpii.v6i1.7245

Fatmawati, I. N., \& Utari, S. (2015). Penerapan levels of inquiry untuk meningkatkan literasi sains siswa SMP tema limbah dan upaya penanggulangannya. Edusains, 7(2), 151-159. doi: https://doi.org/10.15408/es.v7i2.1750 [Indonesian]

Fitriani., Harahap., F., \& Manurung, B. (2018). Biology Scientific Literacy of Indonesian Students: Case Study in Aceh Tamiang - Aceh. International Journal of Research and Review, 5(3), 63-72.

Ghufron, G. (2018). Revolusi Industri 4.0: Tantangan, Peluang, Dan Solusi Bagi Dunia Pendidikan. In Seminar Nasional dan Diskusi Panel Multidisiplin Hasil Penelitian dan Pengabdian Kepada Masyarakat 2018 .1(1). [Indonesian] 
Govindaraj, A., \& Silverajah, V. G. (2017, December). Blending Flipped Classroom and Station Rotation Models in Enhancing Students' Learning of Physics. In Proceedings of the 2017 9th International Conference on Education Technology and Computers (pp. 73-78). doi: https://doi.org/10.1145/3175536.3175543

Hastjarjo, T. D. (2019). Rancangan EksperimenKuasi. Buletin Psikologi,27(2), 187-203. doi: https://doi.org/10.22146/buletinpsikologi.38619 .[Indonesian]

Heath, S. M., Bishop, D. V., Bloor, K. E., Boyle, G. L., Fletcher, J., Hogben, J. H., ... \& Yeong, S. H. (2014). A spotlight on preschool: The influence of family factors on children's early literacy skills. Plos one, 9(4), e95255. doi: https://doi.org/10.1371/journal.pone.0095255

Holbrook, J., \& Rannikmae, M. (2009). The meaning of scientific literacy. International Journal of Environmental and Science Education, 4(3), 275-288.

Horn, M. B., \& Staker, H. (2011). The rise of K-12 blended learning. Innosight institute, 5 .

Ibrahim, M. M., \& Nat, M. (2019). Blended learning motivation model for instructors in higher education institutions. International Journal of Educational Technology in Higher Education, 16(1), 12. doi: https://doi.org/10.1186/s41239-0190145-2

Islam, S., Baharun, H., Muali, C., Ghufron, M. I., Bali, M. M. E. I., Wijaya, M., \& Marzuki, I. (2018, November). To boost students' motivation and achievement through blended learning. In Journal of Physics: Conference Series (Vol. 1114, pp. 1-11). doi: https://doi.org/10.1088/17426596/1114/1/012046

Iswan, I., \& Bahar, H. (2018, July). Penguatan Pendidikan Karakter Perspektif Islam dalam Era Millenial IR. 4.0. In Prosiding Seminar Nasional Pendidikan. 1(1). [Indonesian]

Lalima, D., \& Dangwal, K. L. (2017). Blended learning: An innovative approach. Universal Journal of Educational Research, 5(1), 129-136. doi: https://doi.org/10.13189/ujer.2017.050116

Maza, E. M. T., Lozano, M. T. G., Alarcón, A. C. C., Zuluaga, L. M., \& Fadul, M. G. (2016). Blended learning supported by digital technology and competency-based medical education: a case study of the social medicine course at the Universidad de los Andes, Colombia. International Journal of Educational Technology in Higher Education, 13(1), 1-13. doi: https:// doi.org/10.1186/s41239-016-0027-9

Morton, C. E., Saleh, S. N., Smith, S. F., Hemani, A., Ameen, A., Bennie, T. D., \& Toro-Troconis, M. (2016). Blended learning: how can we optimise undergraduate student engagement?. BMC medical education, 16(1), $195 . \quad$ doi: https://doi.org/10.1186/s12909-016-0716-z

Nofiana, M. (2017). Profil kemampuan literasi sains siswa smp di kota purwokerto ditinjau dari aspek konten, proses, dan konteks sains. JSSH (Jurnal Sains Sosial dan Humaniora), 1(2), 77-84. doi: $\quad$ https://doi.org/10.30595/jssh.v1i2.1682 [Indonesian]

Nurkhin, A., Kardoyo, K., Pramusinto, H., Setiyani, R., \& Widhiastuti, R. (2020). Applying Blended Problem-Based Learning to Accounting Studies in Higher Education; Optimizing the Utilization of Social Media for Learning. International Journal of Emerging Technologies in Learning (iJET), 15(08), 22-39.

doi: https://doi.org/10.3991/ijet.v15i08.12201

Nurrahmah, A., \& Karim, A. (2018). Analisis Kemampuan Pembuktian Matematis Pada Matakuliah Teori Bilangan. JURNAL eDuMath, 4(2), 21-29. doi: https://doi.org/10.26638/je.753.2064

[Indonesian]

Obiedat, R., Eddeen, L. N., Harfoushi, O., Montaha, A. H., Koury, A., \& Alassaf, N. (2014). Effect of blended-learning on academic achievement of students in the University of Jordan. International Journal of Emerging Technologies in Learning (iJET), 9(2), 37-44. doi: https://doi.org/10.3991/ijet.v9i2.3220

OECD (2016), PISA 2015 Assessment and Analytical Framework: Science, Reading, Mathematic and Financial Literacy, PISA, OECD Publishing, Paris, doi: http://dx.doi.org/10.1787/9789264255425-en

OECD (2019). PISA 2018 Results. Where All Students Can Succeed. Volume II. Paris: OECD Publishing. Retrieved September 29, 2020. doi: https://doi.org/10.1787/b5fd1b8f-en

Purwanto, N. (2010). Prinsip-prinsip dan Teknik Evaluasi Pembelajaran. Bandung: Remaja Rosdakarya. [Indonesian]

Rafiola, R., Setyosari, P., Radjah, C., \& Ramli, M. (2020). The Effect of Learning Motivation, Self-Efficacy, and Blended Learning on Students' Achievement in The Industrial Revolution 4.0. International Journal of Emerging Technologies in Learning (iJET), 15(8), 71-82. doi: https://doi.org/10.3991/ijet.v15i08.12525

Ramdani, Y. (2012). Pengembangan instrumen dan bahan ajar untuk meningkatkan kemampuan komunikasi, penalaran, dan koneksi matematis dalam konsep integral. Jurnal Penelitian Pendidikan, 13(1), 44-52. [Indonesian] 
Rasmitadila, R., Widyasari, W., Humaira, M., Tambunan, A., Rachmadtullah, R., \& Samsudin, A. (2020). Using Blended Learning Approach (BLA) in Inclusive Education Course: A Study Investigating Teacher Students' Perception. International Journal of Emerging Technologies in Learning (IJET), 15(2), 72-85. doi: https://doi.org/10.3991/ijet.v15i02.9285

Ridwan, R., Hamid, H., \& Aras, I. (2020). Blended Learning in Research Statistics Course at The English Education Department of Borneo Tarakan University. International Journal of Emerging Technologies in Learning (iJET), 15(07), 61-73. doi: https://doi.org/10.3991/ijet.v15i07.13231

Rojko, A. (2017). Industry 4.0 concept: background and overview. International Journal of Interactive Mobile Technologies (iJIM), 11(5), 77-90. doi: https://doi.org/10.3991/ijim.v11i5.7072

Saritepeci, M., \& Cakir, H. (2015). The effect of blended learning environments on student motivation and student engagement: A study on social studies course. Egitim ve Bilim, 40(177), 203-216. doi: https://doi.org/10.15390/eb.2015.2592

Schober, A., \& Keller, L. (2012). Impact factors for learner motivation in Blended Learning environments. International Journal of Emerging Technologies in Learning (iJET), 7(2012), 37-41. doi: https://doi.org/10.3991/ijet.v7is2.2326

Shadish, W. R., Cook, T. D., \& Campbell, D. T. (2002). Experimental and quasi-experimental designs for generalized causal inference. Boston: Houghton Mifflin. doi: https://doi.org/10.1086/345281

Sinaga, Y., Silitonga, M., \& Djulia, E. (2019). Comparison of scientific literacy skills based on gender in north Labuhanbatu district. International Journal of Humanities Social Sciences and Education, 6(12), 50-54. doi: https://doi.org/10.20431/2349-0381.0612003

Soekisno, R. B. A. (2015). Pembelajaran berbasis masalah untuk meningkatkan kemampuan argumentasi matematis mahasiswa. Infinity Journal, 4(2), 120-139. doi: https://doi.org/10.22460/infinity.v4i2.77 [Indonesian]

Srivastava, D. K., \& Mudholkar, G. S. (2001). Trimmed T2: A robust analog of Hotelling's T2. Journal of Statistical Planning and Inference, 97(2), 343-358. doi: $\quad$ https://doi.org/10.1016/s03783758(00)00239-1

Stockwell, B. R., Stockwell, M. S., Cennamo, M., \& Jiang, E. (2015). Blended learning improves science education. Cell, 162(5), 933-936. doi: https://doi.org/10.1016/j.cell.2015.08.009
Sujarwanto, E., Hidayat, A., \& Wartono, W. (2014). Kemampuan pemecahan masalah fisika pada modeling instruction pada siswa SMA kelas XI. Jurnal Pendidikan IPA Indonesia, 3(1), 65-78. doi: $\quad$ http://dx.doi.org/10.15294/jpii.v3i1.2903 [Indonesian]

Sukartono. 2018. Revolusi Industri 4.0 dan Dampaknya terhadap Pendidikan di Indonesia. http://pgsd.ums.ac.id/wpcontent/uploads/site s/73/2018/12/Materi-Sukartono.pdf. Di akses 1 April 2019. [Indonesian]

Suryapuspitarini, B. K., Wardono, W., \& Kartono, K. (2018, February). Analisis soal-soal matematika tipe Higher Order Thinking Skill (HOTS) pada kurikulum 2013 untuk mendukung kemampuan literasi siswa. In PRISMA, Prosiding Seminar Nasional Matematika (Vol. 1, pp. 876-884). [Indonesian]

Syamsuar, S., \& Reflianto, R. (2018). Pendidikan dan tantangan pembelajaran berbasis teknologi informasi di era revolusi industri 4.0. E-Tech: Jurnal Ilmiah Teknologi Pendidikan, 6(2). doi: https://doi.org/10.24036/et.v2i2.101343. [Indonesian]

Tay, S. I., Lee, T. C., Hamid, N. Z. A., \& Ahmad, A. N. A. (2018). An overview of industry 4.0: Definition, components, and government initiatives. J. Adv. Res. Dyn. Control Syst, 10, 13791387.

Vuksanovic, D., Ugarak, J., \& Korčok, D. (2016). Industry 4.0: The future concepts and new visions of factory of the future development. Conference Sinteza $2016 . \quad$ doi: https://doi.org/10.15308/sinteza-2016-293-298

Wichadee, S. (2017). A development of the blended learning model using Edmodo for maximizing students' oral proficiency and motivation. International Journal of Emerging Technologies in Learning (iJET), 12(02), 137-154. doi: https://doi.org/10.3991/ijet.v12i02.6324

Willems, G., Pison, G., Rousseeuw, P. J., \& Van Aelst, S. (2002). A robust Hotelling test. Metrika, 55(1-2), 125-138. doi: https://doi.org/10.1007/s001840200192 